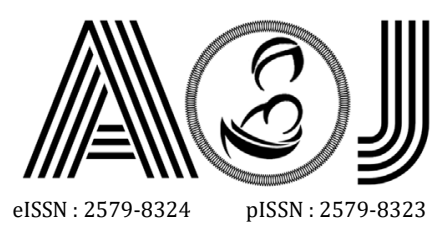

\title{
RESEARCH
}

\section{Description of Knowledge regarding the Application of Independent Isolation and the Application of the Covid-19 Protocol in the New Normal Era for Women of Fertile Age in Indonesia}

\author{
Ida Rahmah Burhan ${ }^{1}$, Abdiana $^{1}$, Zurriyati Hanifa ${ }^{2}$ \\ Affiliation author : 1. Public Health Department, Faculty of Medicine, Andalas University Padang; 2. \\ Medicine Study Program, Faculty of Medicine, Andalas University Padang \\ Correspondence to: Ida Rahmah Burhan, email: idarahmahburhan@med.unand.ac.id, Hp: \\ 0811660401
}

\begin{abstract}
The purpose of this study is to describe the knowledge regarding the application of self isolation and the application of the Covid-19 protocol in the new normal era in women of childbearing age. This type of research is a descriptive study with a cross-sectional design. This research was conducted on 21-24 September 2020 via Google form. The study population was all women of childbearing age in Indonesia. The number of respondents was 1049 people. Data obtained using a validated questionnaire. Most of the respondents were aged over 15-31 years. The results showed that the knowledge of women of childbearing age regarding the application of independent isolation was still low ( $49.5 \%$ of those who answered the questionnaire correctly), the knowledge of women of childbearing age regarding the application of the Covid-19 Protocol at home has reached $78.1 \%$ (high) and knowledge of women of childbearing age regarding the application of the Covid-19 Protocol in the workplace has reached $82 \%$ (high).
\end{abstract}

Keywords: Covid-19, Self-isolation, Covid-19 protocol

\section{INTRODUCTION}

A new corona virus, called Severe Acute Respiratory Syndrome Coronavirus 2 (SARS-CoV-2) spread for the first time in Hubei province, China in December 2019. This virus causes an epidemic disease called coronavirus disease-19 (COVID-19). ${ }^{1}$ Several types of coronavirus are known to cause respiratory tract infections in humans ranging from cold to more serious coughs such as Middle East Respiratory Syndrome (MERS) and Severe Acute Respiratory Syndrome (SARS). However, the number of COVID-19 cases caused by SARS-CoV-2 has increased substantially in the world compared to SARS and MERS so that it requires control measures for a longer period of time. ${ }^{2}$

SARS-CoV-2 is a virus that causes respiratory disease, which is spread to the environment through sneezing or coughing, and contact transmission through the mouth, nose, and eye mucosa. In addition, the COVID-19 pathogen can float in the air in an aerosol form and cause infection in healthy people. ${ }^{3}$ Transmission can also occur through personal 


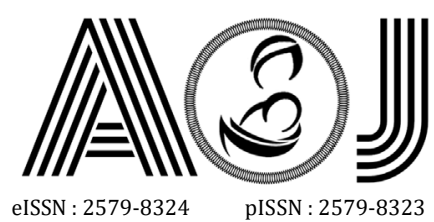

eISSN : 2579-8324
pISSN : 2579-8323

items in the environment around an infected person. Therefore, COVID-19 can be transmitted through direct or indirect contact with an infected person, through surfaces or objects contaminated by an infected person. ${ }^{4}$ COVID-19 positive patients contaminate their bedrooms, toilets and bathrooms, therefore Patients undergoing self-isolation are encouraged to have their own room, toilet and kitchen. ${ }^{1}$

The incubation period or time from infection to the onset of symptoms from Covid-19 varies, from 2 to 14 days with an average incubation period of 5-6 days. ${ }^{5,6}$ Clinical manifestations of COVID-19 start from asymptomatic, symptomatic mild to severe illness and death. Common symptoms include cough, fever and shortness of breath. Other symptoms reported were weakness, malaise, respiratory distress, muscle pain, sore throat, loss of taste and / or smell. ${ }^{7}$ The clinical diagnosis of COVID-19 is based on clinical manifestations, molecular diagnostics by RT-PCR, chest X-ray or CT scan, and Serological blood tests. ${ }^{8,9}$ Independent isolation is aimed at people who have symptoms of Covid-19, have just traveled from the Covid-19 Red Zone area, have a history of contact with Covid-19 sufferers and people without symptoms.

According to WHO data, the number of infected and dead cases increased to $8,708,008$ and 461,715 (December 2019-June 2020), respectively. ${ }^{1}$ In Indonesia, since the implementation of the new normal policy on June 1, 2020 - November 2020, covid-19 cases is increasing every day, even though the government has issued regulations regarding the new normal rules to reduce the rate of Covid-19 cases through restrictions on social interactions and calls for independent isolation. Independent isolation is an activity by limiting interactions with individuals and those around them. This activity can be done at home, or in a place specially provided by the government, such as a guest house. Self-isolation is one of the steps to prevent the spread of Covid-19 which requires good awareness and self-control. Early detection and self-isolation are essential to reduce the rapid spread of infectious diseases. ${ }^{10}$

Women of childbearing age are women who are still of reproductive age (from the time they get their first menstrual period and until the end of menstruation), namely between the ages of 15 - 49 years, with the status of unmarried, married, or widowed, who still have the potential to have offspring. ${ }^{11}$ Women of childbearing age must understand how to control Covid-19 because the pandemic has a significant impact, especially in increasing malnutrition in women. Unavailability of household food, coupled with gender inequality in the distribution of food within households is expected to increase the prevalence of malnutrition, particularly anemia and underweight. ${ }^{12}$

The most important way to control Covid-19 is by implementing the Covid-19 protocol which includes washing hands regularly, using disinfectants, and preventing contact with the face and mouth after interacting with an infected environment (wearing a mask). ${ }^{1}$ The 


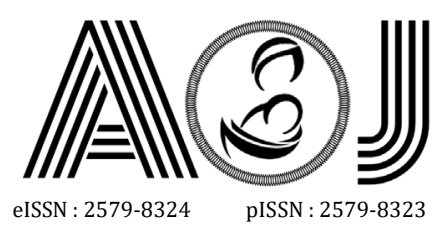

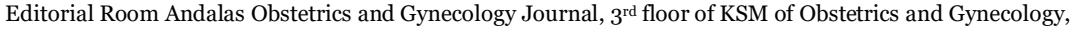

RSUP DR. M. Djamil Padang, Jl. Perintis Kemerdekaan Padang, Sumatera Barat 25127

number of Covid-19 cases continues increased even though there have been calls by the government to carry out independent isolation and carry out the Covid-19 protocol encouraging researchers to do knowledge about the application of independent isolation and the application of the Covid-19 protocol in the new normal era in women of childbearing age.

\section{METHODS}

This type of research is a descriptive study with a cross-sectional design. This research was conducted on 21-24 September 2020. This research was conducted online via Google form. The study population was all women of childbearing age in Indonesia. The number of respondents was 1049 people. Data were obtained using a validated questionnaire made by the Public Health Science or Family Medicine section of the Andalas University Faculty of Medicine. Data were analyzed statistically based on the variables assessed using a computerized program.

\section{RESULTS}

This research was conducted on 1049 respondents on September 21-24 2019.

Table 1. Respondents Characteristics

\begin{tabular}{llll}
\hline Characteristic & & $\mathbf{F}$ & $\mathbf{\%}$ \\
\hline Age & $15-31$ & 982 & 93,6 \\
& $32-49$ & 67 & 6,4 \\
Las Education & Total & 1049 & 100 \\
& Elementary School & 0 & 0 \\
& Junior High School & 23 & 2,2 \\
& Senior High School & 429 & 40,9 \\
Profession & College & 597 & 56,9 \\
& Total & 1049 & 100 \\
& Student & 699 & 66,6 \\
& Office Employees & 74 & 7,1 \\
& Entrepreneur & 57 & 5,4 \\
Demicile & Health workers & 52 & 5 \\
& Teacher & 41 & 3,9 \\
& Others & 52 & 5 \\
& Does not work & 74 & 7,1 \\
& Total & 1049 & 100 \\
& West Sumatera & 731 & 69,7 \\
& Outside West Sumatera & 318 & 31,3 \\
& Total & 1049 & 100 \\
\hline
\end{tabular}

Table 1 shows the characteristics of the respondents consisting of age, latest education, occupation and location. Most of the respondents were aged over 15-31 years, the most 


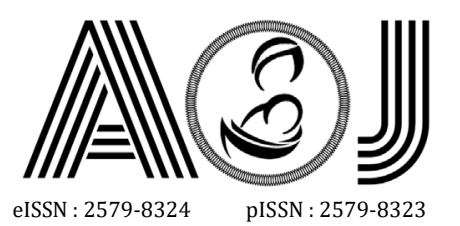

Editorial Room Andalas Obstetrics and Gynecology Journal, $3^{\text {rd }}$ floor of KSM of Obstetrics and Gynecology, RSUP DR. M. Djamil Padang, Jl. Perintis Kemerdekaan Padang, Sumatera Barat 25127

recent education was college, the most occupations were students and the most domicile was in West Sumatra.

Table 2. Knowledge of women of childbearing age regarding the application of self-isolation

\begin{tabular}{|c|c|c|c|}
\hline No & Knowledge component & $f$ & $\%$ \\
\hline \multirow[t]{6}{*}{1.} & $\begin{array}{l}\text { People who have symptoms of COVID-19, live with people who } \\
\text { have symptoms of COVID-19, or have a history of travel to areas } \\
\text { where COVID-19 is endemic must self-isolate }\end{array}$ & & \\
\hline & Strongly disagree & 16 & 1,5 \\
\hline & Disagree & 10 & 1,0 \\
\hline & Neutral & 31 & 3,0 \\
\hline & Agree & 222 & 21,2 \\
\hline & Strongly agree & 770 & 73,4 \\
\hline \multirow[t]{6}{*}{2.} & $\begin{array}{l}\text { Independent isolation carried out at home according to effective } \\
\text { protocol in preventing the spread of COVID-19 }\end{array}$ & & \\
\hline & Strongly disagree & 21 & 2,0 \\
\hline & Disagree & 98 & 9,3 \\
\hline & Neutral & 205 & 19,5 \\
\hline & Agree & 366 & 34,9 \\
\hline & Strongly agree & 359 & 34,2 \\
\hline \multirow[t]{6}{*}{3.} & Self-isolation does not have to be done in a special place & & \\
\hline & Strongly disagree & 48 & 4,6 \\
\hline & Disagree & 179 & 17,1 \\
\hline & Neutral & 392 & 37,4 \\
\hline & Agree & 341 & 32,5 \\
\hline & Strongly agree & 89 & 8,5 \\
\hline \multirow[t]{6}{*}{4.} & $\begin{array}{l}\text { Neighbors who undergo self-isolation according to protocol can } \\
\text { still spread COVID-19 }\end{array}$ & & \\
\hline & Strongly disagree & 99 & 9,4 \\
\hline & Disagree & 283 & 27,0 \\
\hline & Neutral & 396 & 37,8 \\
\hline & Agree & 210 & 20,0 \\
\hline & Strongly agree & 61 & 5,8 \\
\hline \multirow[t]{6}{*}{5.} & $\begin{array}{l}\text { People who have recovered from COVID-19 can no longer } \\
\text { transmit the disease }\end{array}$ & & \\
\hline & Strongly disagree & 472 & 45,0 \\
\hline & Disagree & 384 & 36,6 \\
\hline & Neutral & 113 & 10,8 \\
\hline & Agree & 51 & 4,9 \\
\hline & Strongly agree & 29 & 2,8 \\
\hline \multirow[t]{5}{*}{6.} & $\begin{array}{l}\text { Independent isolation is not necessary for everyone from out of } \\
\text { town if they do not show symptoms }\end{array}$ & & \\
\hline & Strongly disagree & 144 & 13,7 \\
\hline & Disagree & 249 & 23,7 \\
\hline & Neutral & 249 & 23,7 \\
\hline & Agree & 297 & 28,3 \\
\hline
\end{tabular}




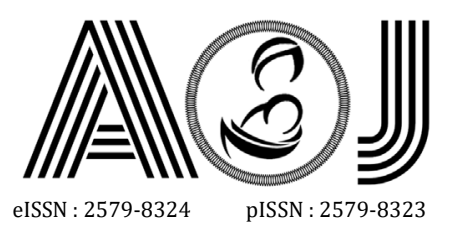

Editorial Room Andalas Obstetrics and Gynecology Journal, $3^{\text {rd }}$ floor of KSM of Obstetrics and Gynecology, RSUP DR. M. Djamil Padang, Jl. Perintis Kemerdekaan Padang, Sumatera Barat 25127

Strongly agree

7. Asymptomatic COVID-19 patients do not endanger other family members if isolated independently at home by implementing health protocols

Strongly disagree

$\begin{array}{ll}172 & 16,4 \\ 399 & 38,0 \\ 324 & 30,9 \\ 124 & 11,8 \\ 30 & 2,9\end{array}$

8. Self-isolation in accordance with health protocols carried out at home increases the likelihood of spreading COVID-19

Disagree

Neutral

Agree

Strongly agree

\begin{tabular}{lll} 
Strongly disagree & 13 & 1,2 \\
Disagree & 6 & 0,6 \\
Neutral & 33 & 3,1 \\
Agree & 203 & 19,4 \\
Strongly agree & 794 & 75,7 \\
\hline Total & 1049 & 100 \\
\hline
\end{tabular}

Table 2. shows the knowledge of women of childbearing age regarding the application of independent isolation, in the first statement there were $94.6 \%$ of respondents who answered correctly, in the second statement there were $69.1 \%$ of respondents who answered correctly, in the third statement there were $41 \%$ of respondents who answered correctly, in the fourth statement there were $36.4 \%$ of respondents who answered correctly, in the fifth statement there were $7.7 \%$ of respondents who answered correctly, in the sixth statement there were $37.4 \%$ of respondents who answered correctly, in the seventh statement there were $14,7 \%$ of respondents who answered correctly, and in the eighth statement there were $95.1 \%$ of respondents who answered correctly.

Table 3. Knowledge of women of childbearing age regarding the application of the Covid-19 Protocol at home

\begin{tabular}{llll}
\hline No & Knowledge component & $\mathrm{f}$ & $\%$ \\
\hline 1. & I wash my hands immediately after traveling from public places & & \\
& when I get home & 13 & 1,2 \\
Strongly disagree & 6 & 0,6 \\
Disagree & 33 & 3,1 \\
Neutral & 203 & 19,4 \\
Agree & 794 & 75,7 \\
Strongly agree & & \\
I took a shower immediately after traveling from a public place & & \\
when I got home & 12 & 1,1 \\
Strongly disagree & 21 & 2,0 \\
Disagree & 199 & 19,0 \\
Neutral & 378 & 36,0
\end{tabular}




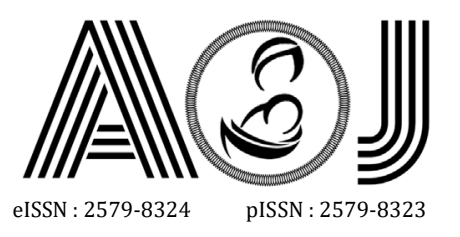

Editorial Room Andalas Obstetrics and Gynecology Journal, $3^{\text {rd }}$ floor of KSM of Obstetrics and Gynecology, RSUP DR. M. Djamil Padang, Jl. Perintis Kemerdekaan Padang, Sumatera Barat 25127

Strongly agree

3. I immediately changed clothes after traveling from public places when I got home

Strongly disagree

Disagree

Neutral

$16 \quad 1,5$

Agree

$79 \quad 7,5$

Strongly agree

4. COVID-19 patients who are undergoing independent isolation at home can share the bathroom and eating utensils with other family members

Strongly disagree

5. Covid-19 patients who are isolated at home independently must wear medical masks while other family members are allowed to wear cloth masks

Strongly disagree

Disagree

Neutral

6. Activities of people infected with COVID-19 must carry out

$86 \quad 8,2$

independent isolation in separate rooms

Strongly disagree

Disagree

$26 \quad 2,5$

Neutral

$72 \quad 6,9$

Agree

Table 3. shows the knowledge of women of childbearing age regarding the implementation of the Covid protocol at home, in the first statement there are $95.1 \%$ of respondents who answered correctly, in the second statement there were $77.8 \%$ of respondents who answered correctly, in the third statement there were $89,9 \%$ of respondents who answered correctly, in the fourth statement there were $82 \%$ of respondents who answered correctly, in the fifth statement there were $34.2 \%$ of respondents who answered correctly, and in the sixth statement there were $89.6 \%$ of respondents who answered correctly. 


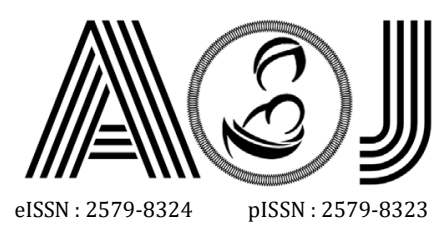

Editorial Room Andalas Obstetrics and Gynecology Journal, $3^{\text {rd }}$ floor of KSM of Obstetrics and Gynecology, RSUP DR. M. Djamil Padang, Jl. Perintis Kemerdekaan Padang, Sumatera Barat 25127

Website:

http://jurnalobgin.fk.unand.ac.id/index.php/JOE

Table 4. Knowledge of women of reproductive age regarding the application of the Covid-19 Protocol in the workplace

\begin{tabular}{|c|c|c|c|}
\hline No & Knowledge component & $\mathrm{f}$ & $\%$ \\
\hline \multirow[t]{6}{*}{1.} & $\begin{array}{l}\text { There must be strict sanctions for people who do not use PPE and } \\
\text { do not apply health protocols }\end{array}$ & & \\
\hline & Strongly disagree & 10 & 1,0 \\
\hline & Disagree & 16 & 1,5 \\
\hline & Neutral & 61 & 5,8 \\
\hline & Agree & 304 & 29,0 \\
\hline & Strongly agree & 658 & 62,7 \\
\hline \multirow[t]{6}{*}{2.} & $\begin{array}{l}\text { I feel safe hanging out in the crowd at close proximity to each } \\
\text { other, who are already wearing masks }\end{array}$ & & \\
\hline & Strongly disagree & 429 & 40,9 \\
\hline & Disagree & 425 & 40,5 \\
\hline & Neutral & 142 & 13,5 \\
\hline & Agree & 30 & 2,9 \\
\hline & Strongly agree & 26 & 2,5 \\
\hline \multirow[t]{6}{*}{3.} & $\begin{array}{l}\text { When there are meals together, I still eat alone by bringing food } \\
\text { to the car or moving to another room with a long distance from } \\
\text { other people }\end{array}$ & & \\
\hline & Strongly disagree & 25 & 2,4 \\
\hline & Disagree & 105 & 10,0 \\
\hline & Neutral & 413 & 39,4 \\
\hline & Agree & 300 & 28,6 \\
\hline & Strongly agree & 206 & 19,6 \\
\hline \multirow[t]{6}{*}{4.} & I don't need to do physical distancing in a public place & & \\
\hline & Strongly disagree & 662 & 63,1 \\
\hline & Disagree & 324 & 30,9 \\
\hline & Neutral & 35 & 3,3 \\
\hline & Agree & 12 & 1,1 \\
\hline & Strongly agree & 16 & 1,5 \\
\hline \multirow[t]{6}{*}{5.} & I always carry a handsanitizer when I travel & & \\
\hline & Strongly disagree & 17 & 1,6 \\
\hline & Disagree & 19 & 1,8 \\
\hline & Neutral & 96 & 9,2 \\
\hline & Agree & 257 & 24,5 \\
\hline & Strongly agree & 660 & 62,9 \\
\hline \multirow[t]{6}{*}{6.} & $\begin{array}{l}\text { In the workplace, it is mandatory to have a COVID } 19 \text { Handling } \\
\text { Team }\end{array}$ & & \\
\hline & Strongly disagree & 11 & 1,0 \\
\hline & Disagree & 12 & 1,1 \\
\hline & Neutral & 169 & 16,1 \\
\hline & Agree & 372 & 35,5 \\
\hline & Strongly agree & 485 & 46,2 \\
\hline \multirow[t]{2}{*}{7.} & $\begin{array}{l}\text { A place for washing hands does not have to be provided in the } \\
\text { workplace }\end{array}$ & & \\
\hline & Strongly disagree & 715 & 68,2 \\
\hline
\end{tabular}




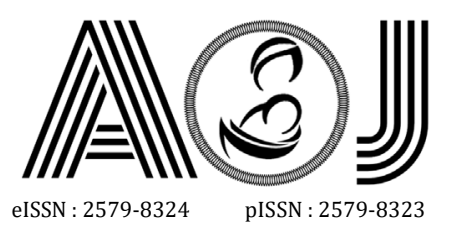

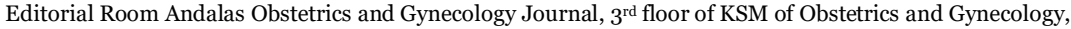
RSUP DR. M. Djamil Padang, Jl. Perintis Kemerdekaan Padang, Sumatera Barat 25127

Disagree

Neutral

Agree

Strongly agree

8.

Independent isolation is not necessary for everyone from out of

town if they do not show symptoms

Strongly disagree

Disagree

Neutral

Agree

Strongly agree
260

23

18

33

472

384

113

51

29

9. My workplace must impose strict sanctions on workers who do not implement health protocols

Strongly disagree

Disagree

Neutral

Agree

Strongly agree
24,8

2,2

1,7

3,1

45,0

36,6

10,8

4,9

2,8

Table 4. shows the knowledge of women of childbearing age regarding the implementation of the Covid protocol at work, in the first statement there were $89.7 \%$ of respondents who answered correctly, in the second statement there were $81.4 \%$ of respondents who answered correctly, in the third statement there were $48,2 \%$ of respondents who answered correctly, in the fourth statement there were $94 \%$ of respondents who answered correctly, in the fifth statement there were $87.4 \%$ of respondents who answered correctly, in the sixth statement there were $81.7 \%$ who answered correctly, in the seventh statement there are $93.6 \%$ of respondents who answered correctly, in the eighth statement there were $81.6 \%$ of respondents who answered correctly and in the ninth statement there were $81.9 \%$ of respondents who answered correctly.

\section{DISCUSSION}

\section{Respondent characteristics}

The data in this study were obtained from 1049 respondents, most of whom were aged over 15-31 years, this may be influenced by the media used in this study, namely by using a goggle form which is more accessible to adults.

\section{Knowledge of women of childbearing age regarding the application of self-isolation}

The knowledge of women of reproductive age regarding the application of independent isolation can be seen in table 2, overall the knowledge of women of reproductive age regarding the application of independent isolation is only $49.5 \%$, which is still low. There are still many women of childbearing age who do not know about how to apply mandatory 


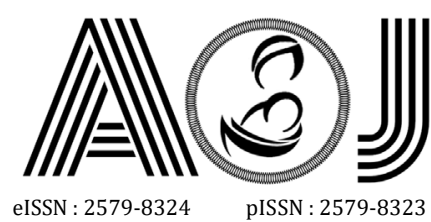

eISSN : 2579-8324
pISSN : 2579-8323

isolation properly. People who need to self-isolate based on the Decree of the Minister of Health of the Republic of Indonesia No. HK.01.07 / MENKES / 382/2020, namely:

1. People who are sick (fever or cough / runny nose / sore throat / other respiratory symptoms), but do not have other comorbidities (diabetes, heart, cancer, chronic lung disease, AIDS, autoimmune diseases)

2. People under surveillance (ODP) who have fever / respiratory symptoms with a history from the country / local transmission area, and / or people who are asymptomatic but have had close contact with a Covid-19 positive patient.

3. People who are positive for Covid-19 but do not show symptoms such as fever, cough or runny nose. People like this are termed People Without Symptoms (OTG).

4. People who are positive for Covid-19 but do not have comorbidities such as diabetes, heart disease, cancer, chronic lung disease, AIDS, autoimmune diseases. ${ }^{13}$

Independent isolation can be carried out at home, not only in government facilities, because the number of Covid patients continues to increase so that government facilities are not sufficient to accommodate them.

Covid-19 transmission can be transmitted through direct or indirect contact with an infected person, through surfaces or objects contaminated by an infected person, so they must have their own room, toilet and also their own kitchen.1 People who have recovered from COVID-19 can no longer transmit disease. Self-isolation carried out at home according to health protocols is effective in preventing the spread of COVID-19. ${ }^{10}$

\section{Knowledge of women of childbearing age regarding the application of the Covid-19 Protocol}

The knowledge of women of childbearing age regarding the application of the Covid-19 Protocol at home can be seen in table 3 , as a whole, women of reproductive age in the community regarding the application of the Covid-19 Protocol in their homes have reached $78.1 \%$, which is quite high. The Covid-19 protocol includes washing hands regularly, using disinfectants and wearing masks. ${ }^{1}$ People are advised to wash their hands immediately after traveling from public places when they get home, take a shower immediately and change clothes after traveling from public places when they arrive at home. ${ }^{11}$ COVID-19 patients who are independently isolated at home must wear medical masks while other family members are allowed to wear cloth masks and activities of people infected with COVID-19 must carry out independent isolation in separate rooms.

The knowledge of women of childbearing age regarding the application of the Covid-19 Protocol in the workplace can be seen in table 4, as a whole, the knowledge of women of childbearing age regarding the application of the Covid-19 Protocol at home has reached $82 \%$, 


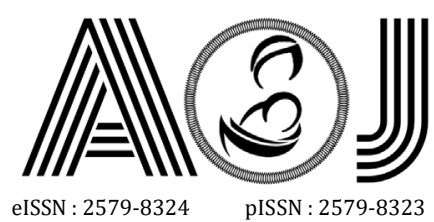

eISSN : 2579-8324
pISSN : 2579-8323

which is quite high. Gathering in a crowd in close proximity to each other even though wearing masks is not safe, social distancing is still the key. When there is a group meal, people should continue to eat by themselves by bringing food to the car or moving to another room far from other people, because otherwise this could lead to the formation of new clusters. Handsanitizer must be carried when traveling and in every workplace it is mandatory to have a COVID 19 Handling Team. Hand washing stations must also be provided in the workplace and the workplace must provide strict sanctions for workers who do not apply health protocols.

Even though many people already know how to implement the Covid-19 protocol, this does not guarantee the high number of people who have already implemented it. The high number of knowledge is not always directly proportional to the attitudes and behavior of society. One of the reasons that the Covid numbers continue to increase is the lack of public awareness. Good knowledge does not always correlate with good awareness. This reduced awareness is due to the "false security" that arose after the enactment of the new normal regulations, where the public assumed that dissemination would not occur if they used masks and washed their hands or used a hand sanitizer. The existence of this fake security is a justification for people to gather without paying attention to distance when interacting. The community returned to interact as usual outside the home and did not undergo independent isolation.

In addition, with the enactment of the new normal regulations, several places that have the potential to become gathering places, such as restaurants and tourist attractions, have reopened with restrictions on the number of visitors. The reopening of several gathering places made people think that this reintroduction was a sign that conditions had improved, whereas in fact the opposite had happened. The number of new covid-19 cases is actually increasing every day. The number of people who undergo proper self-isolation is decreasing.

\section{CONCLUSIONS AND SUGGESTIONS}

In this study, it was found that public knowledge regarding the application of selfisolation and the Covid-19 protocol was still not high. For this reason, the government and health workers should be even more active in educating the public about this matter and the government is expected to impose strict sanctions on people who do not comply with the protocol, because the sanctions will have a deterrent effect on people who violate them. In addition, knowledge is not always directly proportional to attitudes and behavior. The most important thing in carrying out self-isolation and the Covid-19 protocol is public awareness to comply and implement it. The enactment of the new Normal does not mean that the Covid19 case no longer exists, so that people can go outside the house without wearing a mask and 


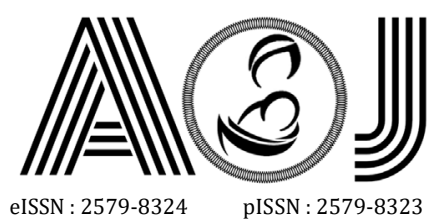

eISSN : 2579-8324
pISSN : 2579-8323

Editorial Room Andalas Obstetrics and Gynecology Journal, $3^{\text {rd }}$ floor of KSM of Obstetrics and Gynecology, RSUP DR. M. Djamil Padang, Jl. Perintis Kemerdekaan Padang, Sumatera Barat 25127

Website:

http://jurnalobgin.fk.unand.ac.id/index.php/JOE

gather in the crowd. Therefore, the public must raise awareness to always carry out the Covid19 protocol and self-isolation properly.

\section{REFFERENCES}

1. Esakandari H ,Afjadi MN, Afjadi JF , Farahmandian N, Miresmaeili SM, Bahreini E. A comprehensive review of COVID-19 characteristics. Biological Procedures Online. 2020.hlm.1-10

2. Corman VM, Landt O, Kaiser M, Molenkamp R, Meijer A, Chu DK, et al. Detection of 2019 novel coronavirus (2019-nCoV) by real-time RT-PCR. Euro Surveill. 2020;25(3).

3. Hou $H$, Wang $T$, Zhang $B$, Luo $Y$, Mao L, Wang $F$, et al. Detection of IgM and IgG antibodies in patients with coronavirus disease 2019. Clin Transl Immunol. 2020;9(5):e01136.

4. Lotfi M, Hamblin MR, Rezaei N. COVID-19: Transmission, prevention, and potential therapeutic opportunities. Clin Chim Acta. 2020;508:254-66. 57. Lauc G, Markotić A, Gornik I, Primorac D. Fighting COVID-19 with water. J Glob Health. 2020;10(1):010344.

5. Comas-Garcia M. Packaging of Genomic RNA in Positive-Sense SingleStranded RNA Viruses: A Complex Story. Viruses. 2019;11(3):253.

6. Mousavizadeh L, Ghasemi S. Genotype and phenotype of COVID-19: Their roles in pathogenesis. J Microbiol Immunol Infect. 2020;S1684-182(20):30082-7.

7. Lovato A, de Filippis C, Marioni G. Upper airway symptoms in coronavirus disease 2019 (COVID-19). Am J Otolaryngol. 2020:102474.

8. Paranjpe I, Russak A, De Freitas JK, Lala A, Miotto R, Vaid A, et al. Clinical Characteristics of Hospitalized Covid-19 Patients in New York City. medRxiv. 2020.

9. Zhu J, Zhong Z, Ji P, Li H, Li B, Pang J, et al. Clinicopathological characteristics of 8697 patients with COVID-19 in China: a meta-analysis. Fam Med Commun Health. 2020;8(2):e000406

10. Rothe C, Schunk M, Sothmann P, et al. Transmission of 2019-nCoV infection from an asymptomatic contact in Germany. N Engl J Med. 2020

11. Depkes RI. Profil Kesehatan Indonesia tahun 2015. Jakarta: Depkes RI. 2016

12. Unicef. Covid-19 dan anak-anak di Indonesia. Jakarta: Unicef.2020

13. Kemenkes. Protokol Kesehatan Bagi Masyarakat di Tempat dan Fasilitas Umum Dalam Rangka Pencegahan dan Pengendalian Corona Virus Disease 2019 (COVID-19). ttps://covid19.go.id/p/regulasi/keputusan-menteri-kesehatan-nomor-hk0107men kes3822020 diakses September 2020 